(E-ISSN : 2615-4978, P-ISSN : 2086-4620)

Vol. IX No 2, Nopember 2018

\title{
Impact Working Capital Terhadap Peningkatan Profitabilitas Pada KSU Cahaya Permata
}

\author{
Risa Ratna Gumilang \\ Sekolah Tinggi Ilmu Ekonomi 11 April \\ risa.rgumilang@gmail.com
}

\begin{abstract}
Abstrak
Penelitian ini bertujuan untuk mengetahui pengaruh modal kerja terhadap tingkat profitabilitas pada KSU (Koperasi Serba Usaha) Cahaya Permata, yaitu dengan metode mengambil data sekunder serta dengan menggunakan analisis data linier untuk mengetahui sejauh mana sebuah koperasi yang notabenenya lebih sederhana dari pada Bank dalam sistem manajemen maupun tata cara pengelolaan keuangannya, dalam meningkatkan profitabilitas untuk keuntungan perusahaan itu sendiri, keunikan penelitian ini yang didasari oleh peneliti untuk melakukan riset penelitian pada KSU Cahaya Permata Bandung. Hasil penelitian ini yaitu Modal kerja berpengaruh signifikan terhadap profitabilitas, karena semakin meningkatnya modal kerja maka semakin meningkat pula tingkat profitabilitas.
\end{abstract}

Kata kunci : modal kerja, tingkat profitabilitas

\section{ABSTRACT}

This study aims to determine the effect of working capital on the level of profitability at KSU Cahaya Permata (Business Multipurpose Cooperative), namely by taking secondary data and using linear data analysis to determine the extent of a creation that is simpler than the Bank in the management system or the procedure for financial management, in increasing profitability for the benefit of the company itself, the uniqueness of this research is based on the researcher to conduct research research at KSU Cahaya Permata. The results of this study are that working capital has a significant effect on profitability, because the increasing working capital increases the level of profitability.

Keywords: working capital, profitability level

\section{PENDAHULUAN}

Pada dasarnya setiap perusahaan akan melakukan berbagai aktivitas untuk mencapai tujuan yang telah ditetapkan. Setiap aktivitas yang dilaksanakan oleh perusahaan selalu memerlukan dana, baik untuk membiayai kegiatan operasional sehari-hari maupun untuk membiayai investasi jangka panjangnya. Dana yang digunakan untuk melangsungkan kegiatan operasional sehari- hari disebut modal kerja.

Modal kerja dibutuhkan oleh setiap perusahaan untuk membiayai kegiatan operasinya sehari-hari, dimana modal kerja yang telah dikeluarkan itu diharapkan akan dapat kembali lagi masuk dalam perusahaan dalam waktu yang pendek melalui hasil penjualan produksinya. Modal kerja yang berasal dari penjualan produk tersebut akan segera dikeluarkan lagi untuk membiayai kegiatan operasional selanjutnya Pengelolaan modal kerja merupakan tanggung jawab setiap manajer atau pimpinan perusahaan. Manajer harus mengadakan pengawasan terhadap modal kerja agar sumber-sumber modal kerja dapat digunakan secara efektif di masa mendatang. Manajer perlu mengetahui tingkat perputaran modal kerja agar dapat menyusun rencana yang lebih baik untuk periode yang akan datang. Selain manajer, kreditur jangka pendek juga perlu mengetahui tingkat perputaran modal kerja suatu perusahaan. Dengan begitu, kreditur jangka pendek akan memperoleh kepastian kapan hutang perusahaan akan segera dibayar. Modal kerja merupakan salah satu komponen penting dalam menjalankan aktivitas perusahaan. Modal kerja yang digunakan diharapkan dapat kembali masuk dalam waktu pendek melalui penjualan. Hal ini dikarenakan modal kerja akan berputar secara terus menerus setiap periodenya dapat dialokasikan kembali untuk membiayai operasi perusahaan. Untuk dapat menentukan jumlah modal kerja yang efisien, terlebih dahulu diukur dari elemen-elemen modal kerjanya. Semakin cepat tingkat perputaran masing-masing elemen modal kerja, maka modal kerja dapat dikatakan efisien. Melalui pengelolaan yang baik, diharapkan modal yang tertanam 
dalam bentuk modal kerja tersebut dapat dimanfaatkan secara efisien dan efektif melalui aktivitas yang dilakukan oleh perusahaan.

Manajemen keuangan berperan penting dalam perencanaan dan pengalokasian modal, karena berhasil atau tidaknya tujuan perusahaan tergantung pada pengelolaan modal kerja. Dalam perencanaan dan pengalokasian modal, manajemen keuangan dituntut untuk mampu melakukan efisiensi. Semua ini diwujudkan dengan menarik suatu keputusan dalam kebijakan menentukan modal yang dibutuhkan. Tujuan perusahaan adalah mendapatkan laba yang maksimal. Keuntungan atau laba merupakan sarana penting untuk mempertahankan kelangsungan hidup perusahaan. Semakin tinggi laba yang diharapkan maka perusahaan akan mampu bertahan hidup, tumbuh, berkembang, dan berdaya saing. Modal kerja sangat erat kaitannya dengan keuntungan atau tingkat profitabilitas perusahaan. Profitabilitas itu sendiri diukur berdasarkan laba bersih yang diterima oleh perusahaan. Laba bersih menunjukkan jumlah penjualan yang dicapai perusahaan dalam satu periode sehingga dapat dijadikan alat ukur terhadap tingkat profitabilitas perusahaan.

KSU Cahaya Permata ialah koperasi yang melakukan beberapa kegiatan ekonomi. KSU Cahaya Permata memiliki program seperti pinjaman atau dana talang, juga sektor penggadaian yakni bisa menitipkan benda berharga seperti alat elektronik, serta surat berharga yang memiliki nilai baik BPKB kendaraan maupun sertifikat rumah.

Pada KSU Cahaya Permata, profitabilitas perusahaan mengukur efektifitas manajemen berdasarkan hasil pengembalian yang dihasilkan dari penjualan dan investasi dengan modal kerja yang memadai dan di dukung dengan peningkatan volume kreditur (peminjam) maka profitabilitas perusahaanpun akan meningkat karena betapa pentingnya arti keuntungan bagi masa depan perusahaan.

\section{TINJAUAN PUSTAKA}

Adapun tujuan dalam penelitian ini adalah untuk mengetahui pengaruh modal kerja terhadap tingkat profitabilitas.

\section{Modal Kerja}

Menurut Sawir (2005), modal kerja adalah keseluruhan aktiva lancar yang dimiliki perusahaan atau dapat pula dimaksudkan sebagai dana yang harus tersedia untuk membiayai kegiatan operasi perusahaan sehari-hari.

Menurut Bambang Riyanto (2004), modal kerja merupakan modal yang digunakan untuk membelanjai atau membiayai usaha sehari-hari atau diharapkan akan kembali dalam waktu yang pendek melalui penjualan barang-barang atau produksinya, maka uang atau dana tersebut akan terus menerus berputar setiap periodenya selama hidup perusahaan.

Menurut Keown et al (2010), Modal kerja adalah investasi total perusahaan pada aktiva lancar atau aktiva yang diharapkan dapat dikonversi menjadi kas dalam waktu satu tahun atau kurang dari satu tahun.

\section{Konsep Modal Kerja}

Menurut Riyanto (2004) modal kerja terdiri dari beberapa konsep, yaitu:

\section{Konsep Kuantitatif}

Modal kerja menurut konsep ini adalah keseluruhan dari jumlah aktiva lancar. Modal kerja dalam pengertian ini sering disebut modal kerja bruto (gross working capital).

\section{Konsep Kualitatif}

Modal kerja menurut konsep ini adalah sebagian dari aktiva lancar yang benar-benar dapat digunakan untuk membiayai operasinya perusahaan tanpa mengganggu likuiditasnya, yaitu yang merupakan kelebihan aktiva lancar di atas hutang lancar. Modal kerja bersih (net working capital) dapat dirumuskan sebagai berikut:

$$
\begin{gathered}
\text { Modal Kerja Bersih } \\
=\text { Total Aktiva Lancar }- \text { Total Hutang Lancar }
\end{gathered}
$$

3. Konsep Fungsional

Konsep ini mendasarkan pada fungsi dari dana dalam menghasilkan pendapatan (income). Setiap dana yang dikerjakan atau digunakan dalam perusahaan adalah dimaksudkan untuk menghasilkan pendapatan. Ada sebagian dana yang digunakan dalam suatu periode accounting tertentu yang seluruhnya langsung menghasilkan pendapatan bagi periode tersebut (current income) dan ada sebagian dana lain yang juga digunakan selama periode tersebut tetapi tidak seluruhnya digunakan untuk menghasilkan current income.

Jenis-jenis modal kerja menurut Riyanto (2004) adalah sebagai berikut:

1. Modal Kerja Permanen (Permanent Working Capital) yaitu modal kerja yang harus tetap ada pada perusahaan untuk dapat menjalankan fungsinya, atau dengan kata lain modal kerja yang secara terus-menerus diperlukan untuk kelancaran usaha. Permanent working capital ini dapat dibedakan dalam: 
a. Modal kerja primer (primary working capital), yaitu jumlah modal kerja minimum yang harus ada pada perusahaan untuk menjamin kontinuitas usahanya.

b. Modal kerja normal (normal working capital), yaitu jumlah modal kerja yang diperlukan untuk menyelenggarakan luas produksi yang normal.

2. Modal kerja variabel (variabel working capital) yaitu modal kerja yang jumlahnya berubah-ubah sesuai dengan perubahan keadaan, dan modal kerja ini dibedakan antara:

a. Modal kerja musiman (seasonal working capital), yaitu modal kerja yang jumlahnya berubah-ubah disebabkan karena fluktuasi musim.

b. Modal kerja siklis (cyclical working capital), yaitu modal kerja yang jumlahnya berubahubah disebabkan karena fluktuasi konjungtur.

c. Modal kerja darurat (emergency working capital), yaitu modal kerja yang besarnya berubah-ubah karena adanya keadaan darurat yang tidak diketahui sebelumnya (misalnya adanya pemogokan buruh, perubahan keadaan ekonomi yang mendadak dan lain-lain).

\section{Perputaran Modal Kerja}

Menurut Riyanto (2004), modal kerja selalu dalam keadaan operasi atau berputar dalam perusahaan selama perusahaan yang bersangkutan dalam keadaan usaha. Periode perputaran modal kerja (working capital turnover period) dimulai dari saat dimana kas diinvestasikan dalam komponenkomponen modal kerja sampai saat dimana kembali lagi menjadi kas. Semakin pendek periode tersebut berarti semakin cepat perputarannya atau semakin tinggi tingkat perputarannya.

Periode perputaran barang dagangan adalah lebih pendek daripada barang yang mengalami proses produksi.

\section{Penentuan Kebutuhan Modal Kerja}

Menurut Sutrisno (2012), besar kecilnya kebutuhan modal kerja terutama tergantung kepada 2 (dua) faktor, yaitu:

1. Perputaran modal kerja, dengan metode ini besarnya modal kerja ditentukan dengan cara menghitung perputaran elemen-elemen pembentuk modal kerja seperti perputaran kas, perputaran piutang dan perputaran persediaan

2. Keterikatan dana adalah jangka waktu yang diperlukan mulai kas ditanamkan ke dalam elemen-elemen modal kerja sampai menjadi kas lagi. Semakin lama periode terikatnya modal kerja akan semakin memperbesar jumlah kebutuhan modal kerja dan sebaliknya.

Sumber modal kerja Menurut Munawir (2001), pada umumnya sumber modal kerja suatu perusahaan dapat berasal dari:

1. Hasil operasi perusahaan merupakan jumlah net income yang tampak dalam laporan rugi laba ditambah dengan depresiasi dan amortisasi.

2. Keuntungan dari penjualan surat-surat berharga, surat berharga jangka pendek yang merupakan salah satu elemen aktiva lancar yang segera dapat dijual yang akan menimbulkan keuntungan bagi perusahaan.

3. Penjualan aktiva tetap sumber lain yang dapat menambah modal kerja adalah hasil penjualan aktiva tetap, investasi jangka panjang, dan aktiva tidak lancar lainnya yang tidak diperlukan lagi oleh perusahaan.

4. Penjualan Saham dan Obligasi, perusahaan dapat mengadakan emisi saham baru atau meminta kepada para pemilik perusahaan untuk menambah modalnya. Dan mengeluarkan obligasi atau bentuk hutang jangka panjang lainnya guna memenuhi kebutuhan modal kerjanya.

Menurut Munawir (2004), Penggunaan atau pemakaian modal kerja akan menyebabkan perubahan bentuk maupun penurunan jumlah aktiva lancar yang dimiliki oleh perusahaan. Penggunaan aktiva lancar yang mengakibatkan turunnya modal kerja, yaitu:

1. Pembayaran biaya atau ongkos-ongkos operasi perusahaan, meliputi pembayaran upah, pembelian bahan atau barang dagangan, dan pembayaran biaya-biaya lainnya.

2. Kerugian-kerugian yang di derita oleh perusahaan karena adanya penjualan surat berharga atau efek serta kerugian yang lainnya.

3. Adanya pembentukan dana atau pemisah aktiva lancar untuk tujuan-tujuan tertentu dalam jangka panjang. Misalnya dana pelunasan obligasi, dana pensiun pegawai, ekspansi dan dana-dana lainnya.

4. Adanya pembelian atau penambahan aktiva tetap dan investasi jangka panjang.

5. Pembayaran hutang jangka panjang meliputi hutang hipotik, hutang obligasi, dan hutang jangka panjang lainnya.

6. Pengambilan uang barang dan dagangan oleh pemilik untuk kepentingan pribadi atau pengambilan keuntungan pada perusahaan 
perorangan dan persekutuan atau pembayaran dividen dalam perseroan terbatas.

Perputaran Kas Menurut Riyanto (2004), kas merupakan aktiva paling likuid atau merupakan salah satu unsur modal kerja yang paling tinggi likuiditasnya yang berarti bahwa semakin besar jumlah kas yang dimiliki suatu perusahaan akan semakin tinggi pula tingkat likuiditasnya. Ini berarti bahwa perusahaan mempunyai risiko yang lebih kecil untuk tidak dapat memenuhi kewajiban finansialnya.

Dari uraian tersebut dapat disimpulkan bahwa kas sangat berperan dalam menentukan kelancaran kegiatan perusahaan, oleh karena itu kas harus direncanakan dan di awasi dengan baik dari segi penerimaan dan pengeluarannya. Menurut Munawir (2004), sumber penerimaan kas berasal dari:

1. Hasil penjualan investasi jangka panjang dan aktiva tetap yang diikuti dengan penambahan kas.

2. Pengeluaran surat tanda bukti barang, baik jangka pendek maupun jangka panjang dan bertambahnya hutang yang diimbangi penerimaan kas.

3. Penjualan atau adanya emisi saham maupun adanya penambahan modal oleh pemilik perusahaan dalam bentuk kas.

4. Adanya penurunan atau berkurangnya aktiva lancar selain kas diimbangi dengan adanya penerimaan kas.

5. Adanya penerimaan kas karena sewa, bunga atau dividen dari investasinya. Sedangkan menurut Munawir (2004), pengeluaran kas dapat di sebabkan adanya transaksi-transaksi sebagai berikut:

a. Pembelian saham dan obligasi sebagai investasi jangka pendek maupun jangka panjang serta adanya pembelian aktiva lainnya.

b. Penarikan kembali saham yang beredar maupun adanya pengambilan kas perusahaan oleh pemilik perusahaan.

c. Pelunasan atau pembayaran angsuran hutang jangka pendek atau jangka panjang.

d. Pembelian barang dagangan secara tunai, adanya pembayaran biaya operasi yang meliputi upah dan gaji, pembelian perlengkapan kantor, pembayaran bunga dan premi asuransi serta adanya persekot biaya maupun persekot pembelian.

e. Pengeluaran kas untuk pembayaran dividen, pembayaran pajak, dan denda- denda lainnya.
Untuk menghitung perputaran kas dapat rumus sebagai berikut:

Perputaran kas

$=$ Penjualan bersih Rata - rata kas

Semakin tinggi perputaran kas ini akan semakin baik. Karena ini berarti semakin tinggi efisiensi penggunaan kasnya.

Perputaran Persediaan Menurut Riyanto (2004), inventory atau persediaan sebagai elemen yang utama dari modal kerja merupakan aktiva yang selalu dalam keadaan berputar, dimana secar terus- menerus mengalami perubahan. Masalah investasi dalam inventory merupakan masalah pembelanjaan aktif, seperti halnya investasi dalam aktiva-aktiva lainnya. Masalah penentuan besar investasi atau alokasi modal dalam inventory mempunyai efek yang langsung terhadap keuntungan perusahaan. Adanya investasi dalam inventory yang terlalu besar dibandingkan dengan kebutuhan akan memperbesar beban bunga, memperbesar biaya penyimpanan dan pemeliharaan gudang, kemungkinan kerugian karena kerusakan, turunnya kualitas, semuanya ini akan memperkecil keuntungan. Untuk mengukur efisiensi persediaan maka perlu diketahui perputaran persediaan (inventory turnover) yang terjadi dengan membandingkan antara harga pokok penjualan dengan nilai rata-rata persediaan yang dimiliki, dapat dinyatakan dengan rumus:

\section{Perputaran persediaan}

= Harga pokok penjualan Rata - rata persediaan

Perputaran persediaan menunjukkan berapa kali dana yang tertanam dalam persediaan berputar dalam suatu periode. Semakin tinggi tingkat perputaran persediaan maka jumlah modal kerja yang semakin rendah. Semakin tinggi tingkat perputaran persediaan akan memperkecil risiko terhadap kerugian yang disebabkan karena penurunan harga atau karena perubahan selera konsumen, disamping itu akan menghemat biaya penyimpanan dan pemeliharaan terhadap persediaan tersebut.

Perputaran Piutang Menurut Soemarso (2004), setiap pemimpin perusahaan selalu menginginkan penjualan barang dagangannya dibayar secara tunai. Namun, di lain pihak penjualan secara kredit justru akan memberi peluang untuk perluasan pasar sehingga dapat menambah laba usaha, meski hal ini bukan tanpa resiko.

Menurut Fest dan Warren (2008) jenis-jenis piutang yang dialihbahasakan oleh Faramita dan Hendrawan diklasifikasikan sebagai berikut: 


\section{Piutang Usaha}

Transaksi paling umum yang menciptakan piutang adalah penjualan barang dagang atau jasa secara kredit. Piutang dicatat dengan mendebit akun piutang usaha dan diklasifikasikan sebagai aktiva lancar.

2. Wesel Tagih Wesel tagih (notes receivable) adalah jumlah yang terhutang bagi pelanggan disaat perusahaan telah menerbitkan surat hutang formal.

\section{Piutang Lain-lain}

Piutang lain-lain biasanya disajikan secara terpisah dalam neraca. Jika piutang ini diharapkan akan tertagih dalam satu tahun, maka piutang tersebut diklasifikasikan sebagai aktiva lancar. Piutang lain-lain meliputi piutang bunga, piutang pajak, dan piutang dari pejabat atau karyawan perusahaan. Piutang selalu dalam keadaan berputar. Periode perputarannya atau periode terikatnya modal dalam piutang adalah tergantung kepada syarat pembayarannya, berarti semakin lama modal terikat pada piutang ini berarti bahwa tingkat perputarannya selama periode tertentu adalah semakin rendah. Perputaran piutang dapat dihitung dengan menggunakan rumus sebagai berikut: Perputaran Piutang $=$ Penjualan Kredit Rata - rata Piutang Perputaran piutang dalam suatu perusahaan tergantung dan bagaimana sebuah perusahaan mengaturnya. Semakin besar tingkat perputaran piutang menandakan semakin singkat waktu antara piutang tercipta karena penjualan kredit dengan pembayaran piutang semakin baik begitu pula sebaliknya.

\section{Definisi Profitabilitas}

Menurut Tobing dan Talankky (2004), profitabilitas adalah kemampuan memperoleh laba, kemampuan persero untuk memperoleh laba dan potensi untuk memperoleh penghasilan pada masa yang akan datang yang dapat diukur dengan Return On Equity (ROE) dan Return On Assets (ROA).

Menurut Sawir (2005), profitabilitas adalah hasil akhir bersih dan berbagai kebijakan dan keputusan manajemen. Menurut Riyanto (2001), profitabilitas adalah kemampuan perusahaan untuk menghasilkan laba selama periode tertentu.

Menurut Sartono (1998), profitabilitas adalah kemampuan perusahaan memperoleh laba dalam hubungannya dengan penjualan, total aktiva maupun modal sendiri. Setiap perusahaan selalu berusaha untuk meningkatkan profitabilitasnya. Jika perusahaan berhasil meningkatkan profitabilitasnya, dapat dikatakan bahwa perusahaan tersebut mampu mengelola sumber daya yang dimilikinya secara efektif dan efisien sehingga mampu menghasilkan laba yang tinggi.

Perusahaan yang memiliki profitabilitas rendah menunjukkan perusahaan tersebut tidak mampu mengelola sumber daya yang dimilikinya , sehingga tidak mampu menghasilkan laba yang tinggi. Cara menilai profitabilitas perusahaan tergantung pada laba dan aktiva atau model mana yang akan dibandingkan satu dengan lainnya.

Menurut Sawir (2008) mengungkapkan bahwa rasio profitabilitas, yaitu:

\section{Margin laba kotor (gross profit margin)}

Margin laba kotor (Gross Profit Margin) berfungsi untuk mengukur tingkat pengembalian keuntungan kotor terhadap penjualan bersihnya. Persamaan untuk mengukur margin laba kotor menurut Riyanto (2011) adalah sebagai berikut:

Margin Laba Kotor = Laba Kotor Penjualan Bersih Laba kotor (gross profit) adalah penjualan bersih (net sales) dikurangi dengan harga pokok penjualan. Penjualan bersih (net sales) adalah total penjualan bersih selama satu tahun.

2. Margin Laba Bersih (Net Profit Margin) Margin laba bersih (net profit margin) berfungsi untuk mengukur tingkat pengembalian keuntungan bersih terhadap penjualan bersihnya dirumuskan sebagai berikut:

Margin Laba Bersih = Laba Bersih Setelah Pajak Penjualan Bersih Nilai margin laba bersih berada di antara nol dan satu. Semakin besar mendekati satu, maka berarti semakin efisien biaya yang dikeluarkan dan semakin besar pula tingkat kembalian keuntungan bersih.

3. Return On Equity (ROE) merupakan tingkat pengembalian atas ekuitas pemilik perusahaan. ROE mengukur kemampuan perusahaan memperoleh laba yang tersedia bagi pemegang saham perusahaan

\section{Hipotesis}

Hipotesis dalam penelitian ini adalah modal kerja berpengaruh secara positif dan signifikan terhadap profitabilitas KSU Cahaya Permata

\section{METODE PENELITIAN}

Jenis dan sumber data penelitian memerlukan data baik deskriptif maupun kuantitatif untuk menguji hipotesis. Data tersebut merupakan fakta yang dikumpulkan dalam penelitian terdiri dari dua jenis, yaitu: 


\section{Data Kuantitatif}

Data berupa angka-angka yang diperoleh dari laporan KSU Cahaya Permata yang dihitung dan data-data lainnya yang menunjang penelitian.

\section{Data Kualitatif}

Data yang diperoleh dari KSU Cahaya Permata yang tidak berbentuk angka, seperti gambaran umum perusahaan dan data-data lain yang menunjang penelitian.

\section{Sumber Data}

Sumber data penelitian adalah sumber subjek dari mana data tersebut didapatkan. Sumber data dalam penelitian adalah data sekunder, yaitu data yang yang diperoleh dari pihak ketiga seperti laporan keuangan perusahaan.

\section{Metode Pengumpulan Data}

Teknik pengumpulan data yang digunakan dalam penelitian ini adalah:

1. Penelitian Perpustakaan yaitu dengan menggunakan literatur- literatur yang ada hubungannya dengan penelitian yang dilakukan dimana akan didapatkan data-data yang dibutuhkan oleh peneliti guna melengkapi hasil dari penelitian.

\section{Dokumentasi}

Teknik ini digunakan untuk mendapatkan data-data yang diperlukan sebagai dasar untuk mengadakan penelitian selanjutnya, yaitu laporan keuangan perusahaan.

\section{Metode Analisis Data}

Analisis modal kerja metode kuantitatif yang digunakan adalah analisis modal kerja, yaitu: konsep kuantitatif, yaitu merupakan kelebihan aktiva lancar di atas hutang lancar. Modal kerja bersih (net working capital) dapat dirumuskan sebagai berikut:

Modal Kerja Bersih = Total Aktiva Lancar Total Hutang Lancar Analisis Return On Invesment (ROI) Analisis rasio profitabilitas, khusus terhadap rasio yang menjadi indikator untuk mengetahui tingkat profitabilitas ialah Return On Invesment (ROI). Return On Invesment (ROI) menunjukkan seberapa banyak laba bersih yang bisa diperoleh dari seluruh kekayaan yang dimiliki perusahaan.

\section{Analisis Regresi Linier Sederhana}

Analisis regresi sederhana adalah alat analisis yang digunakan untuk mengetahui besarnya pengaruh variabel bebas (X) terhadap variabel terikat (Y). Dalam penelitian ini menggunakan metode analisis regresi linier sederhana untuk mengetahui pengaruh modal kerja terhadap tingkat profitabilitas. Model regresi yang digunakan dalam penelitian ini yang telah dimodifikasi adalah sebagai berikut:

$$
\begin{aligned}
\mathrm{PR}= & \alpha+\beta \mathrm{MK} \\
\mathrm{Dimana}: & \\
\mathrm{PR}= & \text { Profitabilitas } \\
\mathrm{MK}= & \text { Modal Kerja } \\
\alpha= & \text { Nilai konstanta, besar nilai } \mathrm{Y} \text { jika } \mathrm{X}=0 \\
\beta= & \text { Nilai arah sebagai penentu yang } \\
& \text { menyatakan perubahan nilai } \mathrm{Y} \text { apabila } \\
& \text { terjadi perubahan nilai X }
\end{aligned}
$$

\section{HASIL DAN PEMBAHASAN}

Tabel 1. Modal Kerja Bersih KSU Cahaya Permata pada tahun 2012 s.d. 2017

\begin{tabular}{ccc}
\hline TAHUN & $\begin{array}{c}\text { MODAL KERJA } \\
\text { BERSIH }\end{array}$ & $\begin{array}{c}\text { PERUBAHAN } \\
(\boldsymbol{\%})\end{array}$ \\
\hline 2012 & $2.316,463$ & $69,2 \%$ \\
2013 & $3.126,79$ & $75,8 \%$ \\
2014 & $5.988,338$ & $81,7 \%$ \\
2015 & $11.896,886$ & $71,8 \%$ \\
2016 & $14.475,741$ & $57,7 \%$ \\
2017 & $16.626,919$ & $54,3 \%$ \\
\hline
\end{tabular}

Tabel 2. Laba Bersih KSU Cahaya Permata pada tahun 2012 s.d. 2017

\begin{tabular}{ccc}
\hline Tahun & $\begin{array}{c}\text { Laba Bersih Setelah } \\
\text { Pajak }\end{array}$ & $\begin{array}{c}\text { Return On } \\
\text { Invesment (ROI) }\end{array}$ \\
\hline 2012 & $1.020,233$ & $28,40 \%$ \\
2013 & $1.212,400$ & $28,00 \%$ \\
2014 & $1.467,906$ & $19,31 \%$ \\
2015 & $1.583,321$ & $9,37 \%$ \\
2016 & $1.418,638$ & $5,57 \%$ \\
2017 & $1.707,205$ & $5,51 \%$ \\
\hline
\end{tabular}

Tabel 3. Hasil Analisis Statistik

\begin{tabular}{lrrc}
\hline \multicolumn{1}{c}{ VARIABLE } & B & T & Sig t \\
Konstanta & 60,601 & 3,182 & 0,303 \\
Profitabilitas & 0,382 & 2,819 & 0,143 \\
& & & \\
R. Square $=0,429$ & & & \\
F $\quad=33,411$ & & & \\
Sig. F $\quad=0,000$ & &
\end{tabular}

\section{Analisis Modal Kerja}

Modal kerja adalah sebagian dari aktiva lancar yang dapat digunakan untuk membiayai operasinya perusahaan tanpa mengganggu likuiditasnya, yaitu merupakan kelebihan aktiva lancar di atas hutang lancar. Modal kerja bersih (net working capital) dirumuskan sebagai berikut:

$$
\text { Modal Kerja Bersih = }
$$

Total Aktiva Lancar - Total Hutang Lancar 
Besarnya modal kerja bersih KSU Cahaya Permata selama tahun 2012, 2013, 2014, 2015, 2016, 2017 adalah sebagai berikut:

Tahun $2012=3.347,303-1.030,84=2.316,463$ atau $69,2 \%$ Tahun $2013=4.127,082-1.000,292=3.126,79$ atau $75,8 \%$ Tahun2014 $=7.329,346-1.341,008=5.988,338$ atau $81,7 \%$ Tahun2015 $=16.560,026-4.663,14=11.896,886$ atau $71,8 \%$ Tahun2016 $=25.098,940-10.623,119=14.475,821$ atau $57,7 \%$ Tahun2017 $=30.615,789-13.988,87=16.626,919$ atau $54,3 \%$

\section{Analisis Return On Investment (ROI)}

Return On Investment (ROI) menunjukkan seberapa banyak laba bersih dari kekayaan yang dimiliki perusahaan. Rasio ini dinyatakan sebagai berikut:

\section{Return on investment $(\mathrm{ROI})=$}

Laba Bersih Setelah Pajak dibagi Total Aktiva x $100 \%$

Return On Invesment (ROI) KSU Cahaya Permata selama tahun 2012 sampai dengan tahun 2017 adalah sebagai berikut:

Tahun $2012=1.020,233$ dibagi $3.592,024 \times 100 \%=28,4 \%$ Tahun $2013=1.212,400$ dibagi $4.329,549 \times 100 \%=28 \%$

Tahun $2014=1.467,906$ dibagi $7.599,615 \times 100 \%=19,31 \%$ Tahun $2015=1.583,321$ dibagi $16.889,452 \times 100 \%=9,37 \%$ Tahun $2016=1.418,638$ dibagi $25.460,457 \times 100 \%=5,57 \%$ Tahun $2017=1.707,205$ dibagi $30.994,205 \times 100 \%=5,51 \%$

\section{Analisis Regresi Linier Sederhana}

Dari Tabel 3, dapat dijelaskan bahwa persamaan regresi yang dihasilkan dalam penelitian ini adalah $\mathrm{PR}=60,601+0,382 \mathrm{x}$. Nilai konstanta dalam penelitian ini adalah 60,601, menjelaskan bahwa apabila variabel Modal Kerja bernilai nol, maka variabel Profitabilitas bernilai 60,601. Nilai regresi sebesar 0,382 pada variabel profitabilitas berarti bahwa apabila variabel Modal Kerja meningkat sebesar satu satuan maka variabel profitabilitas akan meningkat sebesar 0,382. Nilai tersebut menyatakan bahwa Modal Kerja berpengaruh secara signifikan terhadap kenaikan profitabilitas di KSU Cahaya Permata

\section{Pembuktian Hipotesis}

Berdasarkan dari data yang telah dikumpulkan dan analisis data yang telah dilakukan diatas terhadap modal kerja dan profitabilitas pada KSU Cahaya Permata, maka dapat Pada Tabel 3 dapat dilihat bahwa hasil uji $t \quad\left(t_{\text {hitung }}\right)$ Profitabilitas adalah 2,819 dengan taraf signifikansi $0,143, \alpha=0,05, \mathrm{df}=\mathrm{n}-2=6-2=4$ yang berarti didapat tabel $=2,776$. Dengan begitu thitung $(2,819)>t_{\text {tabel }}(2,776)$ yang berarti Ho ditolak dan Ha diterima. Dalam hal ini berarti modal kerja berpengaruh terhadap tingkat profitabilitas pada KSU Cahaya Permata secara signifikan.

\section{KESIMPULAN DAN SARAN}

\section{Kesimpulan}

Dari hasil penelitian dan pembahasan yang telah dilakukan, maka selanjutnya pada bagian penutup tulisan ini penulis mencoba untuk mengambil beberapa kesimpulan sebagai berikut:

1. Modal kerja (working capital) didefinisikan sebagai modal yang digunakan untuk membiayai operasional perusahaan sehari-hari, terutama yang memiliki jangka waktu pendek. Modal kerja yang cukup lebih baik daripada modal kerja yang berlebihan, karena dengan modal kerja yang berlebihan menunjukkan bahwa perusahaan tidak bisa menggunakan dana yang ada dengan baik, sehingga dana tersebut menjadi tidak produktif. Hal tersebut akan berdampak terhadap tingkat pengembalian modal perusahaan atau profitabilitas. Begitu juga sebaliknya modal kerja yang kurang dari cukup akan dapat menjadi penyebab kemunduran atau bahkan kegagalan suatu perusahaan dan menurunkan tingkat profitabilitas.

2. Modal kerja berpengaruh signifikan terhadap profitabilitas, karena semakin meningkatnya modal kerja maka semakin meningkat pula tingkat profitabilitas.

3. Dapat dijelaskan bahwa persamaan regresi yang dihasilkan dalam penelitian ini adalah PR = $60,601+0,382 x$. Nilai konstanta dalam penelitian ini adalah 60,601, menjelaskan bahwa apabila variabel Modal Kerja bernilai nol, maka variabel Profitabilitas bernilai 60,601. Nilai regresi sebesar 0,382 pada variabel profitabilitas berarti bahwa apabila variabel Modal Kerja meningkat sebesar satu satuan maka variabel profitabilitas akan meningkat sebesar 0,382. Nilai tersebut menyatakan bahwa Modal Kerja berpengaruh terhadap kenaikan profitabilitas.

4. Dapat dilihat bahwa hasil uji $t \quad\left(t_{\text {hitung }}\right)$ Profitabilitas adalah 2,819 dengan taraf signifikansi $0,143, \alpha=0,05, \mathrm{df}=\mathrm{n}-2=6-2=$ 4 yang berarti didapat $t_{\text {tabel }}=2,776$. Dengan begitu $t_{\text {hitung }}(2,819)>t_{\text {tabel }}(2,776)$ yang berarti Ho ditolak dan Ha diterima. Dalam hal ini 
berarti ada pengaruh modal kerja terhadap tingkat profitabilitas pada KSU Cahaya Permata.

\section{Saran}

KSU Cahaya Permata sebaiknya meningkatkan modal kerja melalui anggota koperasi dengan program simpan pinjam yang lebih di tingkatkan agar menambah tingkat profitabilitas koperasi, sehingga koperasi akan lebih maju dan berkembang dalam mensejahterakan anggotanya.

\section{DAFTAR PUSTAKA}

Ghozali, Imam, (2006), Statistik Nonparametrik, Semarang: Badan Penerbit Undip.

Houston dan Brigham, (2006), Dasar-dasar Manajemen Keuangan, Jakarta: Salemba Empat.

Indonesia, Ikatan Akuntan, (2007), Standar Akuntansi Keuangan, Jakarta:Edisi Revisi. Salemba Empat.

Munawir, S, (2004), Analisis Laporan Keuangan, Yogyakarta: Edisi Keempat. Liberty.

Riyanto, Bambang, (2004), Dasar-dasar Pembelanjaan Perusahaan, Yogyakarta: Edisi Keempat. Cetakan Kedelapan. BPFE.

Sutrisno, (2012), Manajemen Keuangan Teori Konsep dan Aplikasi, Yogyakarta, Ekonisia. Analisis Kinerja Keuangan dan Perencanaan Keuangan Perusahaan, Jakarta: Gramedia Pustaka Utama.

Weston, J. Thomas E. Copeland, (1995), Manajemen Keuangan, Jakarta: Edisi Revisi. Binarupa Aksara. 